\title{
Community knowledge, attitude and practices on mosquitoes and mosquito-borne viral diseases in Kinshasa, Democratic Republic of the Congo
}

kennedy makola mbanzulu ( $\sim$ mbanzulu.kennedy@sacids.org)

Universite de Kinshasa

Leonard E.G. Mboera

Sokoine University of Agriculture, SACIDS ACE

Roger Wumba

Universite de Kinshasa

Josué K. Zanga

Universite de Kinshasa

Flory K. Luzolo

Universite de Kinshasa

Gerald Misinzo

Sokoine University of Agriculture, Faculty of Veterinary Medicine, SACIDS ACE

Sharadhuli I. Kimera

Sokoine University of Agriculture Faculty of Veterinary Medicine

Research article

Keywords: Knowledge, Attitude, Practices, Mosquitoes, Mosquito-borne viruses, Democratic Republic of the Congo

Posted Date: April 2nd, 2020

DOI: https://doi.org/10.21203/rs.2.14941/v2

License: (1) (i) This work is licensed under a Creative Commons Attribution 4.0 International License. Read Full License 


\section{Abstract}

Background Mosquito-borne viral diseases (MBVD) are among the important human and animal health threats globally. Gaining insights on behaviours and practices of local population on MBVD can improve understanding of socio-demographic and cultural factors to be addressed in intervention packages. This study was carried out to explore community knowledge, attitudes and practices regarding mosquitoes and MBVD in Kinshasa, the Democratic Republic of the Congo (DRC). Methods A cross sectional survey involving heads of household was carried out in Kinshasa, DRC, between January and April 2019. Information on socio-demographic characteristics, knowledge, attitudes and practices on mosquito and MBVD was collected through a questionnaire. Data analysis was performed using Epi Info 7. Results A total of 1,464 representatives were involved in the study. Of these, $69 \%$ were under 44 years of age, $60.7 \%$ were females and the majority (90.2\%) were educated. One-third of the houses had insect window screens, $61.2 \%$ had open garbage cans, $33.4 \%$ had outdoor water storage units, $25.1 \%$ had stagnant water collection and $22.5 \%$ had water containers. The majority $(80.3 \%)$ of the respondent mentioned polluted water bodies as the main mosquito breeding places. Yellow fever $(86.6 \%)$ was the most commonly known MBVD. Overall, $12 \%$ of the respondents knew that mosquitoes are vectors of these viruses. Majority of respondents (72.5\%) felt to be at risk of contracting MBVD. Blocked draining water channels, dirty, agriculture, house and road construction, animal rearing and automobile garages were associated with mosquito abundance. Health professionals, family member, radio/television and/or school/university were the main source of information. Cleaning environment (58\%) and/or use of insecticides (25\%) were the main measures implemented in controlling mosquitoes. Mosquito net ownership (87.4\%) and use (67\%) were high. The greater overall of knowledge score (OR: $1.4 ; p=0.1)$, attitude (OR: 1.22; $p=0.1$ ) were not predictor of good practice. Conclusion Most of the residents of Kinshasa had limited knowledge on the role of mosquitoes in the transmission of pathogenic viruses in both humans and animals. Raising awareness and educational sessions are essential in empowering the community on the correct attitudes and practices in order to effectively manage the risk posed by MBVD.

\section{Background}

Mosquitoes transmit different pathogens that affect human and animal health and impact negatively on food security and socio-economic wellbeing [1-3]. In addition to malaria and lymphatic filariasis, mosquitoes are also vectors of several viral diseases. The most important mosquito-borne viral diseases (MBVD) include Yellow fever, Zika, Dengue, Chikungunya, Rift Valley fever and West Nile [4]. Transmission of MBVD to humans and animals includes multifaceted processes; which are influenced by mosquito and viral genetics, environmental, socio-demographic and anthropological factors $[5,6]$.

For effective interventions, in addition to knowledge on biomedical aspects of the diseases, information on socio-anthropological aspects is equally important. It is critical to explore different local socio-cultural and demographic driving factors of MBVD in order to design appropriate interventions. In the current context of increasing insecticide resistance, limited vaccine options and lack of curative resources; 
integrated approach based on community and individual participation are critical in the effective prevention and control of MBVDs.

There is limited information on community knowledge, attitude and practices (KAP) on MBVD in SubSaharan Africa [7]. Studies outside Africa have shown that KAP on MBVD vary widely across populations and countries [8-13]. Inadequate knowledge is a significant barrier for appropriately empowering local communities and individual interventions against MBVD. Lack of or inadequate community knowledge is likely to be an obstacle in adopting specific prevention and control measures against some specific mosquito species and MBVD 11].

Indeed, mosquito species express different biting behaviour and breeding preferences. Generally, population are often discussing mosquitoes in a global way and do not differentiate between mosquito species. Such conceptualization could pose an obstacle in adoption of specific prevention or control measures towards some specific mosquito species and MBVDs [13]. Contrary to Anopheles, main vector of malaria and O'nyong n'yong virus (ONNV) which present nocturnal activities; Aedes aegypti, the main vector of Yellow Fever virus (YFV), Zika virus (ZIKV), Dengue virus (DENV), Chikungunya virus (CHIKV) present a diurnal activity and preferentially breed in domestic containers and bite in peridomestic locations. Culex pipiens complex, major vector of WNV tend to breed in polluted water bodies containing organic matter [14-18]. Considering such details in educating population could raise their awareness on the vector, the viruses and on adapted control and prevention measures.

Democratic Republic of the Congo (DRC) experiences both tropical and equatorial climate with long rains. The climatic and ecological conditions are optimal for almost all major MBVD of public health importance. MBVD are becoming common and a serious public health problem in DRC [19]. The country is known to be at high risk of YFV transmission, morbidity and mortality [20]. More than 400 people died during the Yellow fever outbreaks of 2016-2017 [6,21]. Kinshasa, the capital city, has experienced four Chikungunya outbreaks during the past two decades [22-24]. Recently, reports on Dengue occurrence have increased [23, 25-27], presence of Zika virus (ZIKV) has been documented [27] and the overall seroprevalence of Rift Valley fever virus (RVFV) has increased [28]. To date, Aedes albopictus has been reported in Kinshasa [29]. These threats of MBVD are not only to the local population of DRC but also to visitors. For instance, the majority of Chikungunya virus infections in Belgium between 2007 and 2012 were imported from DRC [30] and recently, the Japanese and Italian travellers returning from DRC were diagnosed with DENV [31-32]. The evidence of circulating West Nile virus (WNV) in dogs, horses and mosquitoes has been documented in Kinshasa among [33-35]. In the context of inadequate resources for control, there is an immediate need to increase community awareness on MBVD in DRC. This study was therefore carried out to determine community knowledge, attitudes and practices as regards to mosquitoes and MBVDs in Kinshasa, DRC.

\section{Methods}

\section{Study area and design}


In this cross-section study, a questionnaire survey was conducted in four districts of Kinshasa between January and April 2019. Kinshasa has 24 communes (municipalities) grouped into four districts and each commune is divided into neighbourhoods. It has an estimated of $11,855,000$ human population [36]. A multi-stage sampling technique was carried out to select study participants. At the first level three municipalities from each district from Kinshasa were chosen. At the second level, two neighborhoods were selected to guarantee a good coverage of geographical, demographic and socio-economic profiles of the population. The head of household or a representative was systematically selected from neighborhoods. The participants included in this study have complied with the following criteria: (i) aged from 18 years-old or above, (ii) living in the selected neighborhoods, (iii) freely consent to participate in study and being present during interview.

A questionnaire was developed in English, translated into French and administered by face-to-face interview in either Lingala or French depending on the language proficiency of the respondent. The questionnaire contained both closed and opened questions with possibility for the respondent to provide more than one answer. The information sought was related to socio-demographic characteristics of respondents, knowledge about mosquito and MBVD diseases (breeding places, activities, behaviour, vector role, control measures, symptoms), attitudes and practices towards mosquitoes and MBVD. The attitude questions were focused on perception of mosquitoes' impact on daily life and the consciousness about responsibility for individual and community protection against mosquitoes and MBVD. The practices questions captured the information about measures undertaking to reduce or to avoid mosquito bites, mosquito abundance in property (environmental hygiene, use chemical and physical means). To get more insight and accuracy on respondent's practice, additional data were captured by inspection of their residential places and its surroundings (presence of vegetation, stagnant water collection, uncovered storage water unit set outdoor, any potential artificial or natural water container, opened garbage can).

\section{Data Analysis}

The data were entered into Microsoft Excel spreadsheet and statistical analysis was performed using Epi Info Software Version 7 (CDC, Atlanta). Summary of statistics were presented as frequencies and proportions in Tables. Each response to knowledge, attitude and practice question was scored with a scale of zero to five. The sum of each knowledge component (breeding site, times of activity, vector role of mosquito in spreading viruses, arbovirus known or heard prior to the survey, prevention and control measures) was used to the determine the overall knowledge score about MBVD by calculating the mean. The attitude questions sought information on how they perceived the impact of mosquitoes on daily life and their responsibility in prevention and protection. The preventives measures undertaken and the information on description of immediate residential environment of the respondent were included in determination of overall practice score.

Low scores were values less than the mean and high scores were values equal or greater than the mean. The chi square test was used to identify associated factors to the KAP scores by calculating the odds ratios (OR) and the $95 \%$ confidence interval $(\mathrm{Cl})$. $P$ values less than 0.05 were considered statistically 
significant. The sociodemographic characteristic (age, sex, education, occupation, marital status, religion) were considered as independent variables.

\section{Results}

\section{Socio-demographic and environmental characteristics}

A total of 1,464 respondents were involved in the study. Of these, the majority (60.7\%) were females. About $52.5 \%$ of respondents were above 33 years of age and $43.2 \%$ had higher levels of education. Almost half of respondents were married (Table 1). Approximately half of respondents (47.8\%) were owners of the houses. About half (48.2\%) of the households had at least six to 10 members. Children under five years were present in $52.7 \%$ of the households. Most participants (94.6\%) were living in houses built with cement bricks and metal roofs (93.6\%), but only $36.4 \%$ of houses had insect window screens. About $70 \%$ of households were supplied with tap water in their home premises. Majority of the houses (61.2\%) had open garbage cans and $38.7 \%$ had vegetation in their surroundings. One-third $(33.4 \%)$ of the houses had storage water units set outdoors, $25.1 \%$ had stagnant water collections, $22.5 \%$ had potential artificial or natural water containers outdoor (tires, flower pot, small can, box, coconut shell, plastic plate). Domestic animals were found in approximately one third of the respondents' homes (Table 2).

\section{Knowledge}

The majority of respondents stated that stagnant and draining polluted water (80.3\%) and garbage (35\%) were the major mosquito breeding sites. As regards to mosquito biting time, $39 \%$ considered mosquitoes to bite during the night, $31 \%$ during sundown while $30.5 \%$ anytime of the day (Table 3). Yellow fever was the most frequent (86.6\%) MBVD that respondents had heard prior to our study. Others included Chikungunya (13.9\%), Zika (7.5\%) and Dengue (3.7\%). Only a few respondents knew that YFV (12.2\%), CHIKV (5.4\%), ZIKV (1.8\%), DENV (1.5\%) and RVFV (0.6\%) were transmitted by mosquitoes. Almost all respondents $(97.2 \%)$ identified malaria as a disease that is spread by mosquitoes. A fewer respondents inappropriately mentioned typhoid fever, HIV/AIDS, Ebola virus disease (EVD) and trypanosomiasis as mosquito-borne diseases (Table 4). Regarding knowledge on the role of mosquito in spreading zoonoses, only $23.7 \%(348 / 1,464)$ were aware that mosquito can transmit pathogens to animals or exchange pathogens between animals and humans. Of these, 348 respondents, $39.0 \%$ were not able to mention any zoonosis while about $14 \%$ mentioned zoonosis not vectored by mosquito (trypanosomiasis, rabies), $5 \%$ stated EVD and 34\% answered malaria (Table 4).

The majority (70.1\%) of respondents who knew about any MBVD, stated fever as the most common symptom, followed headache (52.4\%), general body pain (21.2\%) and joints pain (18.7\%). Only a few respondents mentioned jaundice $(9.9 \%)$, back pain (4.2\%), haemorrhage $(2.2 \%)$, skin rashes $(1.8 \%)$, other (5.7\%).

Of the 1,464 respondents, the majority mentioned environmental measures such as cleaning and removal of garbage $(64.2 \%)$, draining of standing water $(24.8 \%)$ and proper disposal of empty containers $(10.1 \%)$ 
as the most effective mosquito control measures. Other measures included use insecticide-treated mosquito nets $(41.0 \%)$ and spraying of insecticide (22.2\%). Covering of the water storage containers $(10 \%)$, mosquito screens on house window $(8.8 \%)$ and wearing of long clothes were mentioned by only a few $(1.7 \%)$ respondents (Table 3$)$.

A total of 1,346 (91.9\%) had lower overall score of knowledge related to mosquito and MBVD (Table 5). Knowledge scores related to mosquito breeding places were significantly associated to the respondent's age, marital status, education level and sex. Respondents above 33 years of age (OR: 2.4; 95\%Cl: 1.4-4.2; $p=0.0002$ ), married (OR: $2.2 ; 95 \% \mathrm{Cl}: 1.3-3.7 ; p=0.0016)$, high education level (OR: 2.0; 95\%Cl: 1.2-3.2; $p=0.002$ ) had higher knowledge on mosquito breeding places. The female respondents had low knowledge scores regarding to mosquito breeding places (OR: $0.3 ; 95 \% \mathrm{Cl}: 0.2-0.6 ; p=0.0001)$ and regarding times of mosquito biting activity (OR: $0.8 ; 95 \% \mathrm{Cl}: 0.6-1 ; p=0.03)$ compared to males. The non Christians (OR: $1.3 ; 95 \% \mathrm{Cl}: 0.9-1.7 ; p=0.03$ ) had high score than Christians about times of mosquito of activity. The age, sex, occupation, religion, marital status, education of respondents were not significantly associated with the knowledge about the role of mosquito in zoonosis and arboviruses transmission, arboviral disease, preventions and control measures as well as to the overall knowledge (Table 6).

\section{Attitudes and perceptions}

Approximately, three quarters $(72.5 \%)$ of the respondents were aware about impact of mosquitoes on their daily life. Most (60.7\%) respondents reported being bitten by mosquitoes outdoor in their home places, fewer at recreational places or work places and half of respondents responded were bitten indoors. In all, $44.6 \%$ respondents were regularly bitten and $31.2 \%$ reported sometimes. Overall $90 \%$ of participants were bitten during the dark (sundown 36\%, night 53\%); fewer reported mentioned to be bitten during the day (7.0\%). When asked about activities associated with mosquito abundance, $21 \%$ mentioned drainage and blocked draining water channels, $17.7 \%$ garbage, $14 \%$ farming activities, $10 \%$ house/road construction, $7.7 \%$ animal rearing and automobiles garage (Table 7).

Most respondents (72.9\%) perceived that they were responsible for the prevention and protecting themselves and their households against mosquitoes and MBVD. However, only 37.3\% were aware about their responsibilities at community level. They perceived that mosquitoes and MBVD control and prevention to be the responsibility of the health authorities and national Government (Table 8).

The most familiar sources of information about MBVDs were health professional/hospital (40.2\%). their relatives or family members $(26.1 \%)$. Other important sources were the mass media such as radio or television (25.3\%), schools (17.7\%). Church, megaphone public announcement, Government announcement, newspapers, internet, telephone short messages were less common sources of information (Table 7). About $80 \%$ appeared to observe the correct attitude towards MBVDs. The overall attitude scores were significantly associated to the respondent's age and occupation. Respondents aged over 33 years (OR: $0.8 ; 95 \% \mathrm{Cl}: 0.6-1.0 ; p=0.02$ ) had lower attitude scores compared to those aged 18 to 33 years. Considered together students and medical personnel (OR: $0.002 ; 95 \% \mathrm{Cl}: 1.1-1.9 ; p=0.002$ ) had correct attitude towards to mosquito and MBVDs. The sex, religion, marital status, education of 
respondents and overall knowledge were not significantly associated with the respondent's attitude (Table 9).

\section{Practices regarding vector control}

Slightly more than a half (58.6\%) of the respondents reported cleaning environment, one quarter use of insecticides, another one quarter reported emptying garbage containers and emptying of flowers pots $(11 \%)$ as the measures undertaken to reduce mosquito abundance around their homes. The draining of standing water was mentioned by $16.3 \%$ of respondents and garbage cleaning by $11.3 \%$. Covering of water source or drinking water and/or storage containers was stated by only $10.4 \%$ of respondents.

As regards to measures undertaking to reduce or avoid mosquito bites, a large proportion of the respondents (79\%) stated the use of mosquito nets, fumigation and spraying of insecticide $(15.8 \%)$, mosquito screen on windows (13\%), use of fan (10\%), wearing long clothes $(0.3 \%)$ and praying to God (1\%). High proportions of residents $(67.7 \%)$ confirmed that they did not have any challenge in taking action to prevent or control mosquitoes. Challenges in mosquito control and prevention included lack of money and other resources (42.9\%), limited access to necessary items (19.3\%), not having time (19\%), disbelief in the effectiveness of these preventive measures (12.8\%). Although $87.4 \%$ of the respondents had at least one mosquito net, only $67 \%$ confirmed to have slept under a mosquito net during the previous night. The source of the mosquito nets included national mass distribution campaign (68.8\%), healthcare facilities (15\%) and procurement from shop/market (18.8\%). Almost $45 \%$ of these mosquito nets had holes (Table 10). The overall practice score was lower among $85.7 \%$ of participants. The age, sex, occupation, marital status and education of participants were not significantly associated with their practice. The other believer than Christian (OR: $0.5 ; 95 \% \mathrm{Cl}: 0.3-0.8 ; p=0.003$ ) had lower practices compared to Christians believers. The high overall knowledge (OR: $1.4 ; 95 \% \mathrm{Cl}: 0.8-2.3 ; p=0.1$ ) and attitude (OR: $1.22 ; 95 \% \mathrm{Cl}: 0.9-1,6 ; p=0.1$ ) were not significantly associated with the respondent's good practice.

\section{Discussion}

The present study explored the level of community KAP with regard to mosquitoes and MBVD in Kinshasa, DRC. Although majority of respondents reported that were frequently being bitten by mosquitoes either outdoors or indoors; most of them stated mosquito activities were more intense from sundown to night. Only a few participants knew about daily activity of mosquitoes. High proportion of study participants felt more concerned by health problems that are brought by mosquitoes. The observation of the residence environment of the respondents allowed taking inventory of the diverse types of man-made and natural containers that could serve as mosquito breeding places. This observation was in contrast with good level of general knowledge about environmental preventive measures noted among the majority of respondents and what they confirmed as their usual practices towards control and prevention of mosquitoes. This confirms that often people don't understand properly the meaning of the concept of environmental management [13]. 
Majority of respondents emphasized on environmental cleaning although a high percentage of garbage uncovered cans, vegetation, stagnant water collections and abandoned domestics containers were present in resident's places. In addition, probably due to inadequate water supply in some homes, people have set different water storage units outdoor, being unaware of possible invasion of Aedes mosquitoes [37]. This confirms that the common Aedes breeding habitats are not well known by the majority of the respondents [38]. The most common mosquito breeding places known by the study population was polluted waters bodies. Garbage places were perceived as main drivers leading to mosquitoes abundance. This was in consistency with studies carried out in India $[39,40]$.

The mechanic automobiles activities which are taking places in the city might also contribute to mosquito abundance. Similar reports from Tanzania have indicated that tires are among the most prolific breeding sites for Aedes mosquitoes [41]. Agriculture and construction of roads and houses were also reported among the activities leading to mosquito abundance in Kinshasa. These observations were in consistency with findings reported from Kenya, Tanzania, Sudan and France and the French Antilles $[1,42-44]$. Therefore, the prevention messages for MBVD should raise awareness among all of the actors engaged in the design, materials and all humans resources like architects, landscapers, construction professionals, distributors and installers [44].

Nevertheless, majority of respondents in the current study were unaware about the vector role of mosquitoes in spreading pathogens to animals and their involvement. Although majority of study participants had heard about an Aedes-transmitted virus, Yellow Fever and some few on Chikungunya, Zika and Dengue, the majority of them did not know that these viruses are transmitted to human by mosquitoes. Democratic Republic of the Congo has experienced four Chikungunya and four Yellow Fever outbreaks during the past two decades [22-24,45-48], this could be the reasons that majority of the respondents were aware of the diseases.

The lack of knowledge on the role of mosquitoes in spreading virus in both humans and animals could explain some contradictory attitudes, behaviours and practices noted among study participants. Similar observations have been reported in Jamaica, where the population had poor knowledge of MBVD and poor prevention practices [49]. In contrary, in Belize more than $85 \%$ of the respondents confirmed that DENV, ZIKV, CHIKV, and YVFV are viruses transmitted by mosquitoes and that communities were regularly draining standing water or use insecticides to control mosquitoes [2]. Similar observations have been reported in Colombia, USA and China where the majority of the population were positively involved in source reduction preventive practices $[12,50,51]$.

The appropriate knowledge of MBVD can empower individual to make some effort to prevent or control MBVD in their properties instead of waiting for government intervention. The poor knowledge on MBVD has also been reported for RVF in Kenya, Tanzania, and Sudan $[1,42,43]$. The lack of knowledge is driving MBVD into new areas and leads to loss of life and economic losses $[1,43]$. The high level of dirty, multiple fortuitous markets, higher demographic pressure, inadequate urbanization of Kinshasa Metropolitan are suitable conditions to support Culex mosquito, main vector of WNV and RVFV [52-54]. In DRC, currently 
RVFV activities are increasing [28] and evidence of WNV in domestic dogs and horses have been documented from Kinshasa [34,35]. Regarding the number of household rearing either domestic or livestock animals in this study area, there is also urgent need to raise awareness of population about the role of mosquito in spreading zoonosis.

Participants in current study were less aware about how their involvement as local population can boost controlling mosquito and MBVD in their community. The study participants perceived that they had only the duty for self-protection and for their own household but they not responsible for local community mosquito prevention and control. Similar observations have been reported in a study in Western Australia [55]. These positive attitudes of trusting in Government action offer an opportunity for decision-makers and health actors to maximize their educational activities in this community and to get closer to population through its local structures. Even practically, the respondents did not perceive the responsibility of local community and their role as source of information. It is important that the population perceive that control of mosquito-borne diseases does not only have to rely on individual or household protection but also at the community level. Strengthening cooperation between neighbouring households can also serve as an information channel to improve the knowledge levels of this study population. The financial limitation was mentioned as main hindrance in taking action against mosquitoes for the majority of study population. This could be the reason that the majority of study participants would resort less to control measures that expenditures incurring. Once the health risk is perceived as real threat and priority, population can run to transfer their knowledge into action [13]. But embracing of protective behaviours is a multi-factorial procedure influenced by socio-economic and cognitive factors [56]. In general, household expenditure on protective measures using chemical is high $[2,3]$. So, in limited resource settings it is better to emphasize on environment measures which are more accommodated, simple to implement and very effective too. Simple actions like removing garbage and domestic use containers can reduce over $90 \%$ of larvae abundance and putting window screen, closing door can contribute to avoid over $80 \%$ of mosquito adults in homes [13]. Social mobilization and communication programs including modern channels should be developed with all national, local partners and community leaders. The integration of awareness-raising activities on the prevention and control of mosquito-borne diseases should be encouraged in church, school and university programs to educate the church followers, students and use them as multipliers.

\section{Conclusions}

The findings of this study indicate that the population of Kinshasa lives in an environment conducive for the proliferation of mosquitoes and spread of mosquito-borne diseases. However, the overall community knowledge regarding MBVD was poor both in terms of mosquito biology, prevention and control.

Therefore, there is an urgent need to introduce multiple education programs to raise their awareness and improve their knowledge. Particular emphasis should be placed on environmental sanitation, as it is essential to encourage this population to invest themselves in the hygiene of their living environment, since it is also within their reach. 


\section{Abbreviations}

MBVD: Mosquito-borne viral diseases; YFV: Yellow fever virus; CHIKV: Chikungunya virus; DENV: Dengue virus; ZIKV: Zika virus; RVFV: Rift valley fever virus; WNV: West Nile virus; O'nyong n'yong virus (ONNV); EVD: Ebola virus disease; KAP: Knowledge, attitude, and practice.

\section{Declarations}

\section{Ethical Approval and consent to participate}

The study protocol obtained approval from the Ethical Review Committee of Public Health School of the University of Kinshasa, DRC (Approval number ESP/ CE/058/2019). The informed consent was obtained from all the respondents prior to survey questionnaire administration.

\section{Consent for publication}

All authors consented for the publication of the manuscript

\section{Availability of data and materials}

All data generated or analyzed during the current study are available from the corresponding author on reasonable request.

\section{Competing interests}

There are no competing interests.

\section{Funding}

This study received financial assistance through a scholarship from the Government of the United Republic of Tanzania through World Bank WB-ACE II Grant PAD1436.The funder had role in the study.

\section{Author's Contributions}

KMM designed the study, conducted the field works, performed statistical analysis and prepared the manuscript for publication; LM assisted in developing study questionnaire, revised critically the manuscript; RW assisted in developing study questionnaire, study design and participated in writing the manuscript; JZ participated in study design and conducted the field work, FKL participated in field and assisted in writing the manuscript; GM participated in study design and revised the manuscript; SIK participated in designing the study, assisted in developing study questionnaire. All authors read and approved the final version of the manuscript.

\section{Acknowledgements}


The authors would like to thank both authorities of Department of Tropical Medicine and Faculty of Medicine of the University of Kinshasa for granting permission to carry out this study. The authors are also grateful to the finalist students from faculties of Medicine of both Université Libre de Kinshasa and Université Réverend Kim of Kinshasa for being helpful during the field works.

\section{References}

1. Abdi IH, Affognon HD, Wanjoya AK, Onyango-Ouma W, Sang R. Knowledge, Attitudes and Practices (KAP) on Rift Valley Fever among Pastoralist Communities of ljara District, North Eastern Kenya. PLoS Negl Trop Dis. 2015; 9 (11):e0004239

2. Duman-Scheel M, Eggleson KK, Achee NL, Grieco JP, Hapairai LK. Mosquito control practices and perceptions: An analysis of economic stakeholders during the Zika epidemic in Belize, Central America. PLoS One 2018; 13(7)

3. Thuilliez J, Bellia C, Dehecq J-S, Reilhes O. Household-level expenditure on protective measures against mosquitoes on the island of La Réunion, France. PLoS Negl Trop Dis. 2014; 8(1):e2609

4. Statistics for Mosquito-Borne Diseases \& Deaths. http://www.mosquitoreviews.com/mosquitostatistics [Accessed on 10 August 2019]

5. Asebe Gulich G. Epidemiology, Driving Factors, Transmission and Control Options of Zika Virus: A Review.J Infect Dis Ther 2016; 04(02)

6. Kraemer MUG, Faria NR, Reiner RC, Golding N, Nikolay B, Stasse S, et al. Spread of yellow fever virus outbreak in Angola and the Democratic Republic of the Congo 2015-16: a modelling study. Lancet Infect Dis. 2017; 17(3):330-8

7. Braack L., Gouveia de Almeida AP, Cornel AJ., Swanepoel R \& De Jager C. Mosquito-borne arboviruses of African origin: review of key viruses and vectors. Parasites \& Vectors 2018; 11: 29

8. Whiteman A, Mejia A, Hernandez I, Loaiza JR. Socioeconomic and demographic predictors of resident knowledge, attitude, and practice regarding arthropod-borne viruses in Panama. BMC Public Health.2018; 18:1261

9. Corrin T, Waddell L, Greig J, Young I, Hierlihy C, Mascarenhas M. Risk perceptions, attitudes, and knowledge of chikungunya among the public and health professionals: a systematic review. Trop Med Health. 2017; 45:21

10. Mouchtouri VA, Papagiannis D, Katsioulis A, Rachiotis G, Dafopoulos K, Hadjichristodoulou C. Knowledge, Attitudes, and Practices about the Prevention of Mosquito Bites and Zika Virus Disease in Pregnant Women in Greece. Int J Environ Res Public Health 2017; 14(4)

11. Potter A, Jardine A, Neville PJ. A Survey of Knowledge, Attitudes, and Practices in Relation to Mosquitoes and Mosquito-Borne Disease in Western Australia. Front Public Health 2016; 4:32

12. Liu X, Wan F, Cirendunzhu null, Cirenwangla null, Bai L, Pengcuociren null, et al. Community knowledge and experience of mosquitoes and personal prevention and control practices in Lhasa, Tibet. Int J Environ Res Public Health. 2014; 11(9):9919-37 
13. Leslie TE, Carson M, van Coeverden E, De Klein K, Braks M, Krumeich A. An analysis of community perceptions of mosquito-borne disease control and prevention in Sint Eustatius, Caribbean Netherlands. Glob Health Action 2017; 10: 1350394

14. Harrington LC, Fleisher A, Ruiz-Moreno D, Vermeylen F, Wa CV, Poulson RL, et al. Heterogeneous Feeding Patterns of the Dengue Vector, Ae aegypti, on Individual Human Hosts in Rural Thailand. PLoS Negl Trop Dis. 2014; 8(8)

15. Dambach $P$, Schleicher M, Korir P, Ouedraogo S, Dambach J, Sié A, et al. Nightly Biting Cycles of Anopheles Species in Rural Northwestern Burkina Faso. J Med Entomol. Jun 2018; 55(4):1027-34

16. Skiff Jj, Yee Da. Behavioral Differences Among Four Co-occurring Species of Container Mosquito Larvae: Effects of Depth and Resource Environments. J Med Entomol. March 2014; 51(2):375-81

17. Ajamma YU, Villinger J, Omondi D, Salifu D, Onchuru TO, Njoroge L, et al. Composition and Genetic Diversity of Mosquitoes (Diptera: Culicidae) on Islands and Mainland Shores of Kenya's Lakes Victoria and Baringo. J Med Entomol.2016; 53(6):1348-63

18. Medone P, Hernï Ndez-Suï Rez CM. «Swimming mosquitoes»: a key stepping stone to prevent Dengue, Zika and Chikungunya: an educative experience in Colima, Mexico. Health Educ Res. 2019; 34(4):389-99

19. Mbanzulu KM, Mboera LEG, Luzolo FK, Wumba R, Misinzo G, Kimera SI. Mosquito-borne viral diseases in the Democratic Republic of the Congo: a review. Parasites Vectors. 2020; 13:103

20. Africa WHORO for. Mapping the risk and distribution of epidemics in the WHO African Region: a technical report. W H O. Regional Office for Africa; 2016. https://apps.who.int/iris/handle/10665/206560[Accessed on 10 August 2019]

21. Otshudiema JO, Ndakala NG, Mawanda E-TK, Tshapenda GP, Kimfuta JM, Nsibu L-RN, et al. Yellow Fever Outbreak - Kongo Central Province, Democratic Republic of the Congo, August 2016.MMWR Morb Mortal Wkly Rep. 2017;66(12):335-8

22. Muyembe-Tamfum JJ, Peyrefitte CN, Yogolelo R, Mathina Basisya E, Koyange D, Pukuta E, et al. Epidemic of Chikungunya virus in 1999 and 200 in the Democratic Republic of the Congo. Med Trop Rev Corps Sante Colon. 2003;63(6):637-8

23. Ido E, Ahuka S, Karhemere S, Shibata K, Kameoka M, Muyembe JJ.Dengue virus infection during an outbreak of chikungunya virus in Democratic Republic of Congo Annales africaines de médecine. 2017. Available on: https://anafrimed.net

24. Mintela C. Epidémie de Chikungunya confirmée à Kinshasa; https://www.academia.edu/38387381 [Accessed on 9 August 2019]

25. Malekani MJ, Mccollum AM, Monroe B, Malekani V, Mulumba M, Nguete B. Karhemere SR.Cas de dengue chez les patients suspects de Chikungunya à Kinshasa. Annales africaines de médecine. 2014. https://anafrimed.net [Accessed on 10 August 2019]

26. Makiala-Mandanda S, Ahuka-Mundeke S, Abbate JL, Pukuta-Simbu E, Nsio-Mbeta J, Berthet N, et al. Identification of Dengue and Chikungunya Cases Among Suspected Cases of Yellow Fever in the Democratic Republic of the Congo. Vector Borne Zoonotic Dis Larchmt N. 2018; 18(7):364-70 
27. Willcox AC, Collins MH, Jadi R, Keeler C, Parr JB, Mumba D, et al. Seroepidemiology of Dengue, Zika, and Yellow Fever Viruses among Children in the Democratic Republic of the Congo. Am J Trop Med Hyg. Sept 2018; 99(3):756-63

28. Georges TM, Justin M, Victor M, Marie KJ, Mark R, Léopold MMK. Seroprevalence and Virus Activity of Rift Valley Fever in Cattle in Eastern Region of Democratic Republic of the Congo. $J$ Vet Med. 2018; 8:4956378

29. Bobanga T, Moyo M, Vulu F, Irish SR. First Report of Aedes albopictus (Diptera: Culicidae) in the Democratic Republic of Congo. Afr Entomol. 2018; 26(1):234-6

30. VAN DEN Bossche D, Cnops L, Meersman K, Domingo C, VAN Gompel A, VAN Esbroeck M. Chikungunya virus and West Nile virus infections imported into Belgium, 2007-2012. Epidemiol Infect. 2015; 143(10):2227-36

31. Yamamoto SP, Yu Kasamatsu Y, Kanbayashi D, Kaida A, Michinori Shirano M et al.,Dengue Virus in Traveler Returning to Japan from the Democratic Republic of the Congo, 2015. JJID. 2019, 2018.554.Available on: https://www.jstage.jst.go.jp/article

32 Colavita F, Vairo F, Carletti F, Boccardo C ,Ferraro F, laiani G, Moghazi Sa et al.,2020. Full-length genome sequence of a dengue serotype 1 virus isolate from a traveler returning from Democratic Republic of Congo to Italy, July 2019. IJFD; 92: 46-48

33. Mbanzulu KM, Wumba R, Mukendi JK, Zanga JK,Shija F, Bobanga TL et al.Mosquito-borne viruses circulating in Kinshasa, Democratic Republic of the Congo Int. J. Infect. Dis. 2017; 57: 32-37. 31

34. Cabre O, Grandadam M, Marié J-L, Gravier P, Prangé A, Santinelli Y, et al. West Nile Virus in horses, sub-Saharan Africa. Emerg Infect Dis. 2006; 12(12):1958-60

35. Davoust B, Leparc-Goffart I, Demoncheaux J-P, Tine R, Diarra M, Trombini G, et al. Serologic surveillance for West Nile virus in dogs, Africa. Emerg Infect Dis. 2014; 20(8):1415-7

36. Wikipedia Kinshasa Population. https://en.wikipedia.org/w/index.php [Accessed 10 August 2019]

37. Baak-Baak CM, Arana-Guardia R, Cigarroa-Toledo N, Puc-Tinal M, Coba-Tún C, Rivero-Osorno V, et al. Urban Mosquito Fauna in Mérida City, México: Immatures Collected from Containers and Stormwater Drains/Catch Basins. Southwest Entomol. 2014; 39(2): 291-306

38. Medone P, Hernï Ndez-Suï Rez CM. «Swimming mosquitoes»: a key stepping stone to prevent Dengue, Zika and Chikungunya: an educative experience in Colima, Mexico. Health Educ Res. 2019; 34(4):389-99

39. Boratne AV, Jayanthi V, Datta SS, Singh Z, Senthilvel V, Joice YS. Predictors of knowledge of selected mosquito-borne diseases among adults of selected peri-urban areas of Puducherry. $2010 \mathrm{~J}$ Vector Borne Dis.47(4): 249-256

40. Tenglikar PV, Hussain M, Nigudgi S, Ghooli S. Knowledge and Practices Regarding Mosquito borne disease among people of an urban area in Kalaburgi, Karnataka. NtI J Community Med 2016; 7(3):3 
41. Mboera, LEG, Mweya, CN, Rumisha SF, Tungu PK, Stanley G, Makange MR, Misinzo G, et al.The risk of Dengue virus transmission in Dar es Salaam, Tanzania during an epidemic period of 2014. PLoS Negl Trop Dis 10(1): e004313. doi: 10.137 1/journal.pntd.0004313

42. Shabani SS, Ezekiel MJ, Mohamed M, Moshiro CS. Knowledge, attitudes and practices on Rift Valley fever among agro pastoral communities in Kongwa and Kilombero districts, Tanzania. BMC Infect Dis. 2015; $15: 363$

43. Hassan OA, Affognon H, Rocklöv J, Mburu P, Sang R, Ahlm C, et al. The One Health approach to identify knowledge, attitudes and practices that affect community involvement in the control of Rift Valley fever outbreaks. PLoS Negl Trop Dis 2017 ; 11(2)

44. Claeys C, Robles C, Bertaudiere-Montes V, Deschamps-Cottin M, Megnifo HT, Pelagie-Moutenda R, et al. Facteurs socio-écologiques contribuant à l'exposition des populations humaines aux piqûres des moustiques vecteurs de la dengue, du chikungunya et du zika: une comparaison entre France métropolitaine et Antilles françaises. Environ Risques Santé. 2016; 15(4):318-25

45. WHO. Yellow fever in the Democratic Republic of the Congo. Geneva: World Health Organisation; 2010. http://www.who.int/csr/_07_19a /Accessed on 9 Aug 2019

46. WHO. Yellow fever in the Democratic Republic of Congo. Geneva: World Health Organisation; 2013. http://www.who.int/csr/don/2013_06_14_yello w-feve r/en/. /Accessed on 9 Aug 2019

47. WHO. Yellow fever Democratic Republic of the Congo. Geneva: World Health Organisation; 2014. http://www.who.int/csr/don/02-june-2014-yello w-fever -drc/en/.Accessed on 9 Aug 2019

48. WHO. Situation report yellow fever. Geneva: World Health Organisation; 2016. http://apps.who.int/iris/bitst ream/10665 /25066 1/1/yello wfeve rsitrep280 ct16-eng.pdf?ua /Accessed on 9 Aug 2019

49. Alobuia WM, Missikpode C, Aung M, Jolly PE. Knowledge, Attitude, and Practices Regarding Vectorborne Diseases in Western Jamaica. Ann Glob Health. 2015;81(5):654-63

50. Ramírez GIJ, Álvarez LSB. Knowledge, Attitudes and Practices Regarding Dengue, Chikungunya, and Zika and their Vector Aedes Aegypti in Villavicencio, Colombia. The Open Public Health Journal, 2017, $10,80-89$

51. Morse W, Izenour K, McKenzie B, Lessard S, Zohdy S. Perceptions and practices of mosquito-borne diseases in Alabama: is concern where it should be? BMC Public Health 2019; 19: 987

52. Karch S, Asidi N, Manzambi Z, Sa-Laun J. Culicidianfauna and its nuisance in Kinshasa (Zaire).Bulletin de la Société de la Pathologie Exotique. 1993; 86: 68-75

53. Herrington JE .Pre-West Nile virus outbreak: perceptions and practices to prevent mosquito bites and viral encephalitis in the United States. Vector Borne Zoonotic Dis. 2003; Winter; 3(4):157-73

54. Mweya CN, Kimera SI, John Bukombe JK, Mboera LEG (2013). Predicting distribution of Aedes aegypti and Culex pipiens complex, potential vectors of Rift Valley fever virus in relation to disease epidemics in East Africa.Infection Ecology and Epidemiology 3: 21748

55. Mainali S, Lamichhane RS, Clark K, Beatty S, Fatouros M, Neville P, et al. "Looking over the Backyard Fence": Householders and Mosquito Control. Int J Environ Res Public Health. 2017; 14: 246 
56. Fritzell C, Raude J, Adde A, Dusfour I, Quenel P, Flamand C. Knowledge, Attitude and Practices of Vector-Borne Disease Prevention during the Emergence of a New Arbovirus: Implications for the Control of Chikungunya Virus in French Guiana. PLoS Neg/ Trop Dis. 2016; 10(11):e0005081

\section{Tables}

Table 1: Socio-demographic characteristics of participants in the study on mosquito and mosquito-borne viral diseases in Kinshasa

\begin{tabular}{|c|c|c|}
\hline Variable & No. of respondents & Percent \\
\hline \multicolumn{3}{|l|}{ Age Group } \\
\hline 18-33 years & 702 & 47.9 \\
\hline 34-70.years & 762 & 52.5 \\
\hline \multicolumn{3}{|l|}{ Sex } \\
\hline Male & 575 & 39.3 \\
\hline Female & 889 & 60.7 \\
\hline \multicolumn{3}{|l|}{ District } \\
\hline Tshangu & 509 & 34.8 \\
\hline Mont-Amba & 388 & 26.5 \\
\hline Funa & 207 & 14.1 \\
\hline Lukunga & 360 & 24.6 \\
\hline \multicolumn{3}{|l|}{ Marital status } \\
\hline Unmarried & 737 & 50.3 \\
\hline Married & 727 & 49.7 \\
\hline \multicolumn{3}{|l|}{ Education level } \\
\hline Low education level & 831 & 56.7 \\
\hline High education level & 633 & 43.2 \\
\hline \multicolumn{3}{|l|}{ Occupation } \\
\hline Medical personnel or student & 303 & 20.7 \\
\hline Other & 1161 & 79.3 \\
\hline \multicolumn{3}{|l|}{ Religion } \\
\hline Christian & 1234 & 84.3 \\
\hline Other & 230 & 15.7 \\
\hline
\end{tabular}

Table 2: Household and immediate environment characteristics of participants residencies in Kinshasa 


\begin{tabular}{lll}
\hline Variable & No. of respondents & Percent \\
\hline Household size & & \\
$\leq 5$ & 632 & 43.1 \\
$6-10$ & 706 & 48.2 \\
10 & 126 & 8.6 \\
Presence of Child under 5 years old & 772 & 52.7 \\
Home Ownership & & \\
Tenant & 764 & 52.2 \\
Owner & 700 & 47.8 \\
Source of water supply & & \\
Tap water on the home premise & 1024 & 69.9 \\
Tap water away from home premise & 382 & 26.0 \\
Well on the home premise & 17 & 1.2 \\
Well away from home premise & 49 & 3.3 \\
Types of house & & \\
Cement brick & 1385 & 94.6 \\
Sheet metal & 53 & 3.6 \\
Straw, clay, timber (wood) & 26 & 1.8 \\
Types of house roof & & \\
Sheet metal & 1370 & 93.6 \\
Straw & 94 & 6.4 \\
Presence of net (insect screens) on windows & 533 & 36.4 \\
Immediate surrounding house description & & \\
Vegetation & 567 & 38.7 \\
Stagnant water collection & 368 & 25.1 \\
Storage water unit set outdoor & 490 & 33.4 \\
Any potential artificial or natural water container outdoor & 330 & 22.5 \\
An opened garbage can & 897 & 31.3 \\
Domestic animals keeping (rearing) & 459 &
\end{tabular}

Table 3. Knowledge related to mosquito biology, vector role and preventives measures 


\begin{tabular}{|c|c|c|}
\hline Variable & No. of respondents & Percent \\
\hline \multicolumn{3}{|l|}{ Breeding places for mosquitoes } \\
\hline Drain and stagnated polluted water & 1178 & 80.3 \\
\hline Garbage & 526 & 35.9 \\
\hline Unsafe waste disposal compost pit & 137 & 9.3 \\
\hline Pits, drainage open underground soakage pits & 141 & 9.6 \\
\hline Clean water collection & 66 & 4.5 \\
\hline Ditches, ponds & 148 & 10.1 \\
\hline Water storage tanks & 80 & 5.4 \\
\hline Small container & 26 & 1.7 \\
\hline Storage and other water storage jars & 24 & 1.6 \\
\hline Vehicle tires & 72 & 4.9 \\
\hline Coconut shells and broken utensils & 35 & 2.3 \\
\hline Cracks in walls, tree hole & 63 & 4.3 \\
\hline I don't know & 62 & 4.2 \\
\hline Other & 28 & 1.9 \\
\hline \multicolumn{3}{|l|}{ Times of the day mosquito can bite } \\
\hline Daily (morning, afternoon) & 63 & 4.3 \\
\hline Sundown & 454 & 31.0 \\
\hline Night & 571 & 39.0 \\
\hline Anytime & 447 & 30.5 \\
\hline I don't know & 36 & 2.4 \\
\hline \multicolumn{3}{|l|}{ Season of the year mosquito are most frequent } \\
\hline Rain season & 704 & 48.0 \\
\hline Dry season & 354 & 24.1 \\
\hline Both seasons & 350 & 23.9 \\
\hline I don't know & 56 & 3.8 \\
\hline \multicolumn{3}{|l|}{ Can mosquitoes transmit disease to animals? } \\
\hline Yes & 288 & 19.7 \\
\hline No & 1134 & 77.4 \\
\hline I don't know & 42 & 2.9 \\
\hline \multicolumn{3}{|l|}{ Can mosquitoes spread disease between animals and humans } \\
\hline Yes & 348 & 23.7 \\
\hline No & 1090 & 74.5 \\
\hline I don't know or don't believe & 26 & 1.8 \\
\hline \multicolumn{3}{|l|}{ Preventive measures } \\
\hline Hold the environment clean, remove garbage or any uncovered container & 1090 & 74.4 \\
\hline Use Mosquito bed net & 601 & 41.0 \\
\hline Keep cover over the water source/storage unit container & 151 & 10.3 \\
\hline Remove standing water/stagnant water & 363 & 24.8 \\
\hline Spray insecticide & 326 & 22.2 \\
\hline Fumigation & 102 & 6.2 \\
\hline Use repellent & 50 & 3.4 \\
\hline Use fan & 67 & 4.5 \\
\hline Put mosquito screen (net) on house window & 130 & 8.8 \\
\hline Wearing long clothes & 25 & 1.7 \\
\hline I don't know & 33 & 2.2 \\
\hline Other (gasoline oil, detergent, ...) & 22 & 1.8 \\
\hline
\end{tabular}


Table 4: Awareness on Knowledge of MBDV diseases and vector role of mosquito in their transmission to human and animals

\begin{tabular}{|c|c|c|c|}
\hline & $\begin{array}{l}\text { Disease can be transmitted } \\
\text { by mosquito }(\mathrm{N}=1464)\end{array}$ & $\begin{array}{l}\text { Being aware MBVD prior } \\
\text { to survey }(\mathrm{N}=1464)\end{array}$ & $\begin{array}{l}\text { MBD that can be transmitted } \\
\text { between human and animals }(\mathrm{N}=348)\end{array}$ \\
\hline & n (\%) & n (\%) & n (\%) \\
\hline Malaria & $1423(97.2)$ & & $119(34.2)$ \\
\hline Yellow fever & $179(12.2)$ & $1269(86.6)$ & $9(2.5)$ \\
\hline Chikungunya & $79(5.4)$ & $204(13.9)$ & $3(0.8)$ \\
\hline Zika & $27(1.8)$ & $111(7.5)$ & 0.4 \\
\hline Dengue & $22(1.5)$ & $55(3.7)$ & \\
\hline $\begin{array}{l}\text { Rift Valley } \\
\text { fever }\end{array}$ & $9(0.6)$ & $26(1.7)$ & $3(0.8)$ \\
\hline West Nile fever & & $11(0.7)$ & \\
\hline O’nyong 'nyong & $2(0.1)$ & $8(0.5)$ & $3(0.8)$ \\
\hline Arbovirus & $14(0.9)$ & & \\
\hline Filariasis & $1(0.07)$ & & $3(0.8)$ \\
\hline Trypanosomiasis & $17(1.2)$ & & $29(8.3)$ \\
\hline Typhoid fever & $69(4.7)$ & & $11(3.1)$ \\
\hline Ebola & $28(1.9)$ & & $20(5.7)$ \\
\hline HIV & $17(1.1)$ & & $3(0.8)$ \\
\hline Rabies & & & $16(4.6)$ \\
\hline Others & $49(3.4)$ & & $8(2.2)$ \\
\hline I don't know & $22(1.5)$ & & $136(39.0)$ \\
\hline
\end{tabular}

Table 5. KAP score about mosquito and mosquito-borne viral diseases (MBVD) in Kinshasa, 2019 


\begin{tabular}{|c|c|c|c|}
\hline riable & Effective & Percent & IC $95 \%$ \\
\hline \multicolumn{4}{|c|}{ ore of knowledge about breeding site } \\
\hline $\mathrm{w}$ & 1392 & 95.1 & 93.8-96.1 \\
\hline gh & 72 & 4.9 & $3.8-6.1$ \\
\hline \multicolumn{4}{|c|}{ ore of knowledge about mosquitoes period of activity } \\
\hline $\mathrm{w}$ & 1018 & 69.5 & $67.0-71.8$ \\
\hline gh & 446 & 30.5 & 28.1-32.9 \\
\hline \multicolumn{4}{|c|}{ ore of knowledge about role of mosquitoes in spreading zoonoses } \\
\hline $\mathrm{w}$ & 977 & 66.7 & $64.2-69.1$ \\
\hline gh & 487 & 33.3 & 30.6-35.7 \\
\hline \multicolumn{4}{|c|}{ ore of knowledge about vector role of mosquitoes in arbovirus transmission } \\
\hline $\mathrm{w}$ & 1208 & 82.5 & $80.4-84.4$ \\
\hline gh & 256 & 17.5 & $15.5-19.5$ \\
\hline \multicolumn{4}{|c|}{ ore of knowledge about arbovirosis } \\
\hline $\mathrm{w}$ & 1407 & 96.1 & $94.9-97.0$ \\
\hline gh & 57 & 3.9 & 2.9-5.0 \\
\hline \multicolumn{4}{|c|}{ ore of knowledge about mosquito control and prevention } \\
\hline $\mathrm{w}$ & 1358 & 92.8 & $91.2-94.0$ \\
\hline gh & 1.1 & 7.2 & $5.9-8.7$ \\
\hline \multicolumn{4}{|c|}{ rerall score of knowledge } \\
\hline $\mathrm{w}$ & 1346 & 92.0 & $90.4-93.2$ \\
\hline gh & 118 & 8.0 & $6.7-9.6$ \\
\hline \multicolumn{4}{|c|}{ rerall score of attitude } \\
\hline $\mathrm{w}$ & 298 & 20.3 & $36.9-42.0$ \\
\hline gh & 1166 & 79.7 & $57.9-63.3$ \\
\hline \multicolumn{4}{|c|}{ rerall score of practice } \\
\hline $\mathrm{W}$ & 1255 & 85.7 & 83.8-87.4 \\
\hline gh & 209 & 14.3 & $12.5-16.2$ \\
\hline
\end{tabular}


Table 6. Socio-demographic characteristics of participants associated with high level of knowledge about mosquitoes and mosquito-borne viral diseases (MBVD) in Kinshasa, 2019 


\begin{tabular}{|c|c|c|c|c|}
\hline riable & OR & $\overline{X^{2}}$ & $\begin{array}{l}\text { IC } \\
95 \%\end{array}$ & $P$ \\
\hline \multicolumn{5}{|c|}{ ctors associated with high score of knowledge about breeding site } \\
\hline re group of 34-70.years & 2.4 & 11.5 & $\begin{array}{l}1.4- \\
4.2\end{array}$ & 0.0002 \\
\hline male sex & 0.3 & 14.1 & $\begin{array}{l}0.2- \\
0.6\end{array}$ & 0.0001 \\
\hline arried & 2.2 & 9.6 & $\begin{array}{l}1.3- \\
3.7\end{array}$ & 0.0016 \\
\hline st secondary education level & 2.0 & 7.6 & $\begin{array}{l}1.2- \\
3.2\end{array}$ & 0.002 \\
\hline edical personnel or student & 0.8 & 0.003 & $\begin{array}{l}0.4- \\
1.5\end{array}$ & 0.5 \\
\hline sn Christian & 0.9 & 0.003 & $\begin{array}{l}0.5- \\
1.8\end{array}$ & 0.5 \\
\hline
\end{tabular}

actors associated with high score of knowledge about mosquitoes period of activity

re group of 34-70.Years

$\begin{array}{llll}1.3 & 7.6 & 1.1- & 0.002\end{array}$

1.7

male sex

$\begin{array}{llll}0.8 & 3.1 & 0.6- & 0.03\end{array}$

1.0

arried

$\begin{array}{llll}1.0 & 0.1 & 0.8- & 0.3\end{array}$

1.3

st secondary education level

$0.00 \quad 0.8 \quad 0.8-\quad 0.4$

1.2

edical personnel or student

$\begin{array}{llll}1.0 & 0.15 & 0.7- & 0.3\end{array}$

1.2

on Christian

$1.3 \quad 0.003 \quad 0.5$

0.003

1.8

ctors associated with high score of knowledge about role of mosquitoes in reading zoonosis

re group of 34-70.Years

$\begin{array}{llll}0.9 & 0.0 & 0.7- & 0.5\end{array}$

1.2

male sex

$\begin{array}{llll}0.8 & 2.6 & 0.6- & 0.05\end{array}$

1.0

arried

$\begin{array}{llll}0.9 & 1.1 & 0.7- & 0.1\end{array}$

1.0

st secondary education level

$\begin{array}{llll}1.0 & 0.6 & 0.8- & 0.4\end{array}$

1.3

edical personnel or student

$\begin{array}{llll}0.9 & 0.3 & 0.6- & 0.2\end{array}$


on Christian

$\begin{array}{llll}1.1 & 0.5 & 0.8- & 0.2 \\ & & 1.5\end{array}$

.ctors associated with high score of knowledge about vector role of mosquitoes in bovirus transmission

'oup age of 34-70.Years

$1.0 \quad 0.3 \quad 0.8-\quad 0.2$

male sex

$0.8 \quad 1.9 \quad 0.6-\quad 0.08$

1.1

arried

$\begin{array}{llll}1.0 & 0.2 & 0.8- & 0.4\end{array}$

1.4

st secondary education level

$0.9 \quad 0.3 \quad 0.6-\quad 0.2$

1.2

ədical personnel or student

$1.2 \quad 1.2 \quad 0.8-\quad 0.1$

1.6

her believer than Christian

$\begin{array}{llll}1.3 & 2.4 & 0.9- & 0.06 \\ & & 1.9\end{array}$

ictors associated with high score of knowledge about arboviruses

'oup age of 34-70.Years

$0.8 \quad 0.09 \quad 0.5-\quad 0.3$

1.5

male sex

$\begin{array}{llll}0.6 & 2.0 & 0.3- & 0.07\end{array}$

1.1

arried

$0.7 \quad 1.0 \quad 0.4-\quad 0.1$

1.2

st secondary education level

$1.1 \quad 0.2 \quad 0.6-\quad 1.2$

2.0

adical personnel or student

$1.0 \quad 0.0 \quad 0.5-\quad 0.5$

1.9

on Christian

$\begin{array}{llll}1.7 & 2.8 & 0.9- & 0.05\end{array}$

3.3

.ctors associated with high score of knowledge about mosquito control and evention

'oup age of 34-70.Years

$\begin{array}{lll}0.9 \quad 0.00 & 0.6- & 0.5 \\ & & 1.4\end{array}$

male sex

$\begin{array}{llll}1.1 & 2.0 & 0.7- & 0.3\end{array}$

arried

$0.7 \quad 1.0 \quad 0.5-\quad 0.1$

1.2

st secondary education level

$\begin{array}{llll}1.2 & 0.9 & 0.8- & 0.1\end{array}$


edical personnel or student

sn Christian

ictors associated with high global score of knowledge

oup age of 34-70.Years

male sex

arried

st secondary education level

edical personnel or student

on Christian

$\begin{array}{llll}0.8 & 0.4 & 0.5- & 0.2 \\ & & 1.3 & \\ & & & \\ 1.1 & 0.05 & 0.6- & 0.3 \\ & & 1.8 & \end{array}$

$\begin{array}{llll}1.1 & 0.16 & 0.7- & 0.3\end{array}$

1.6

$\begin{array}{llll}1.1 & 0.3 & 0.7- & 0.2\end{array}$

2.0

$1.2 \quad 1.3 \quad 0.8-0.1$

1.8

$\begin{array}{llll}1.0 & 0.08 & 0.7- & 0.3\end{array}$

1.5

$\begin{array}{llll}0.8 & 0.4 & 0.5- & 0.2\end{array}$

1.3

$1.2 \quad 0.6 \quad 0.7-\quad 0.2$

1.6

Table 7: Attitudes related to mosquito and mosquito-borne viral diseases 


\begin{tabular}{|c|c|c|}
\hline Variable & No. of respondents & Percent \\
\hline \multicolumn{3}{|l|}{ Main source of the information } \\
\hline Health professional/hospital & 529 & 40.2 \\
\hline Family & 344 & 26.1 \\
\hline Radio/Television & 333 & 25.3 \\
\hline School, college, university & 233 & 17.7 \\
\hline Neighbours & 117 & 8.9 \\
\hline Community leaders and volunteers & 100 & 7.6 \\
\hline Megaphone public or Government announcement & 74 & 5.0 \\
\hline Internet, Newspapers, SMS & 74 & 5.0 \\
\hline Church/Mosque & 15 & 1.2 \\
\hline Other (traditional healer, ) & 25 & 1.9 \\
\hline \multicolumn{3}{|l|}{ Impact of mosquitoes on daily life } \\
\hline Health risk & 1061 & 72.5 \\
\hline Nuisance & 380 & 25.9 \\
\hline No concern & 7 & 0.4 \\
\hline I don't know & 30 & 2.0 \\
\hline Other (disease, malaria, death) & 103 & 7.0 \\
\hline \multicolumn{3}{|l|}{ In which locations are you often bitten? } \\
\hline Indoor & 741 & 50.6 \\
\hline Outdoor while I am at home & 890 & 60.7 \\
\hline At work place indoor & 14 & 0.9 \\
\hline Outdoor while at work place, recreational place & 119 & 8.1 \\
\hline Everywhere & 62 & 4.2 \\
\hline No & 24 & 1.6 \\
\hline \multicolumn{3}{|l|}{ How often do you get bitten? } \\
\hline Rarely & 343 & 23.4 \\
\hline Sometimes & 468 & 31.9 \\
\hline Regularly & 653 & 44.6 \\
\hline \multicolumn{3}{|l|}{ During which times of the day are often bitten? } \\
\hline Daily time (morning, afternoon) & 102 & 7.0 \\
\hline Sundown & 528 & 36.0 \\
\hline Night & 778 & 53.8 \\
\hline Any time & 177 & 12.0 \\
\hline \multicolumn{3}{|c|}{ Activity in your community leading to mosquito abundance } \\
\hline Agriculture & 206 & 14.0 \\
\hline Animal rearing & 113 & 7.7 \\
\hline House building, Road construction & 157 & 11.6 \\
\hline Drainage and all blocked draining water channels & 310 & 21.1 \\
\hline Garbage & 260 & 17.7 \\
\hline Mechanic or automobile garage & 12 & 0.8 \\
\hline Church services/Prayers & 14 & 0.9 \\
\hline Witchcraft/sorcery & 14 & 0.9 \\
\hline Absence sewage water draining system & 29 & 1.9 \\
\hline Erosion, flooding, proximity to the river & 15 & 1.1 \\
\hline Market, high population density & 5 & 0.3 \\
\hline None & 279 & 19.0 \\
\hline I don't know & 223 & 15.2 \\
\hline
\end{tabular}


Table 8. Awareness about responsibility in the control and prevention of mosquitoes and mosquito-borne diseases

\begin{tabular}{lll}
\hline & Self protection and household & Community \\
\hline Individual responsibility & $1068(72.9)$ & $\mathrm{n}(\%)$ \\
Household head & $128(8.7)$ & $546(37.3)$ \\
Family members & $40(2.7)$ & $114(7.7)$ \\
Local community population & $17(1.2)$ & $7(0.5)$ \\
Health authorities & $223(15.2)$ & $62(4.2)$ \\
Local government administration & $24(1.6)$ & $326(22.2)$ \\
National government & $173(11.8)$ & $50(3.4)$ \\
Both government and population & & $245(11.8)$ \\
God & $8(0.5)$ & $96(6.6)$ \\
None one & $18(1.2)$ & $2(0.1)$ \\
I don't know & 84 & $153(10.4)$ \\
\hline
\end{tabular}

Table 9. Characteristics of participants associated with appropriated attitude towards to mosquito and mosquito-borne diseases (MBD) in Kinshasa, 2019

\begin{tabular}{lllll}
\hline riable & OR & $\mathrm{X}^{2}$ & IC 95\% & $P$ \\
\hline ictors associated to appropriated attitude towards MBDs & & & & \\
re group of 34-70.Years & 0.8 & 3.5 & $0.6-1.0$ & 0.02 \\
male Sex & 0.9 & 0.3 & $0.7-1.1$ & 0.2 \\
arried & 1.0 & 0.006 & $0.8-1.2$ & 0.4 \\
st secondary education level & 1.0 & 0.1 & $0.8-1.2$ & 0.3 \\
edical personnel or student & 1.4 & 7.7 & $1.1-1.9$ & 0.002 \\
sn Christian & 0.8 & 0.9 & $0.6-1.1$ & 0.1 \\
gh score of knowledge & 1.2 & 0.9 & $0.8-1.8$ & 0.1 \\
\hline
\end{tabular}

Table 10: Practices related to mosquito and mosquito-borne diseases 


\begin{tabular}{|c|c|c|}
\hline Variable & No. of respondents & Percent \\
\hline \multicolumn{3}{|l|}{ Measures undertaking to reduce mosquito abundance in property } \\
\hline Put cover over the water source/drinking water/ storage unit/container & 153 & 10.4 \\
\hline Empty flower pots/vases regularly & 160 & 10.9 \\
\hline Cleaning environment & 858 & 58.6 \\
\hline Emptying other water containers served by garbage collection & 363 & 24.8 \\
\hline Fumigating & 95 & 6.5 \\
\hline Removing garbage & 166 & 11.3 \\
\hline Use of insecticides & 380 & 25.9 \\
\hline Remove standing /stagnant water & 239 & 16.3 \\
\hline Nothing & 42 & 2.9 \\
\hline Use bed net & 68 & 4.6 \\
\hline Close the house door & 6 & 0.4 \\
\hline \multicolumn{3}{|l|}{ Measures undertaking to reduce or to avoid mosquito bites } \\
\hline Put mosquito screen on house windows & 197 & 13.4 \\
\hline Sleep under bed net during day & 138 & 9.4 \\
\hline Sleep under bed net during night & 1158 & 79.1 \\
\hline Use of mosquito repellent during day & 19 & 1.3 \\
\hline Use of mosquito repellent during night & 44 & 3.0 \\
\hline Stay indoors & 34 & 2.3 \\
\hline Use of fans & 153 & 10.4 \\
\hline Fumigating and spraying my home & 232 & 15.8 \\
\hline Pray God & 15 & 1.0 \\
\hline Nothing & 48 & 3.2 \\
\hline Wear long clothes & 5 & 0.3 \\
\hline Other & 48 & 3.2 \\
\hline Household having at least a mosquito bed net & 1280 & 87.4 \\
\hline Slept under mosquito bed net last night & 982 & 67.0 \\
\hline \multicolumn{3}{|l|}{ Source of mosquito bed net supply } \\
\hline Mass distribution campaign & 873 & 68.8 \\
\hline Shop/Market & 239 & 18.8 \\
\hline Health facilities & 191 & 15.0 \\
\hline Other & 26 & 2.0 \\
\hline Mosquito bed net with hole on it & 538 & 43.4 \\
\hline \multicolumn{3}{|l|}{ Any challenges in implementing preventive measures } \\
\hline Yes & 474 & 32.3 \\
\hline No & 990 & 67.7 \\
\hline \multicolumn{3}{|l|}{ Types of challenges } \\
\hline Have no time to apply these preventive measures & 72 & 15 \\
\hline Lack of money and resources & 204 & 42.9 \\
\hline Limited access to necessary items & 92 & 19.3 \\
\hline Not priority for me & 34 & 7.1 \\
\hline I don't believe these preventive measures are effective & 61 & 12.8 \\
\hline Risk is less & 15 & 2.9 \\
\hline Other & 13 & 2.7 \\
\hline
\end{tabular}


Table 11. Characteristics of participants associated with good practice towards to mosquito and mosquito-borne viral diseases (MBVD) in Kinshasa,

\begin{tabular}{lllll}
\hline riable & OR & $\mathrm{X}^{2}$ & IC 95\% & $P$ \\
\hline ictors associated to appropriated attitude towards MBD & & & & \\
re group of 34-70.Years & 1.0 & 0.01 & $0.7-1.3$ & 0.4 \\
male sex & 1.2 & 2.1 & $0.9-1.7$ & 0.07 \\
arried & 1.0 & 0.00 & $0.7-1.3$ & 0.4 \\
st secondary education level & 1.0 & 0.02 & $0.7-1.3$ & 0.4 \\
edical personnel and student & 0.8 & 0.2 & $0.6-1.2$ & 0.3 \\
sn Christian & 0.5 & 6.4 & $0.3-0.8$ & 0.003 \\
gh score of knowledge & 1.4 & 1.6 & $0.8-2.3$ & 0.1 \\
spropriated attitude & 1.2 & 1.5 & $0.9-1.6$ & 0.1 \\
\hline
\end{tabular}

\section{Additional File}

Additional file 1: Survey Questionnaire.

Figures 


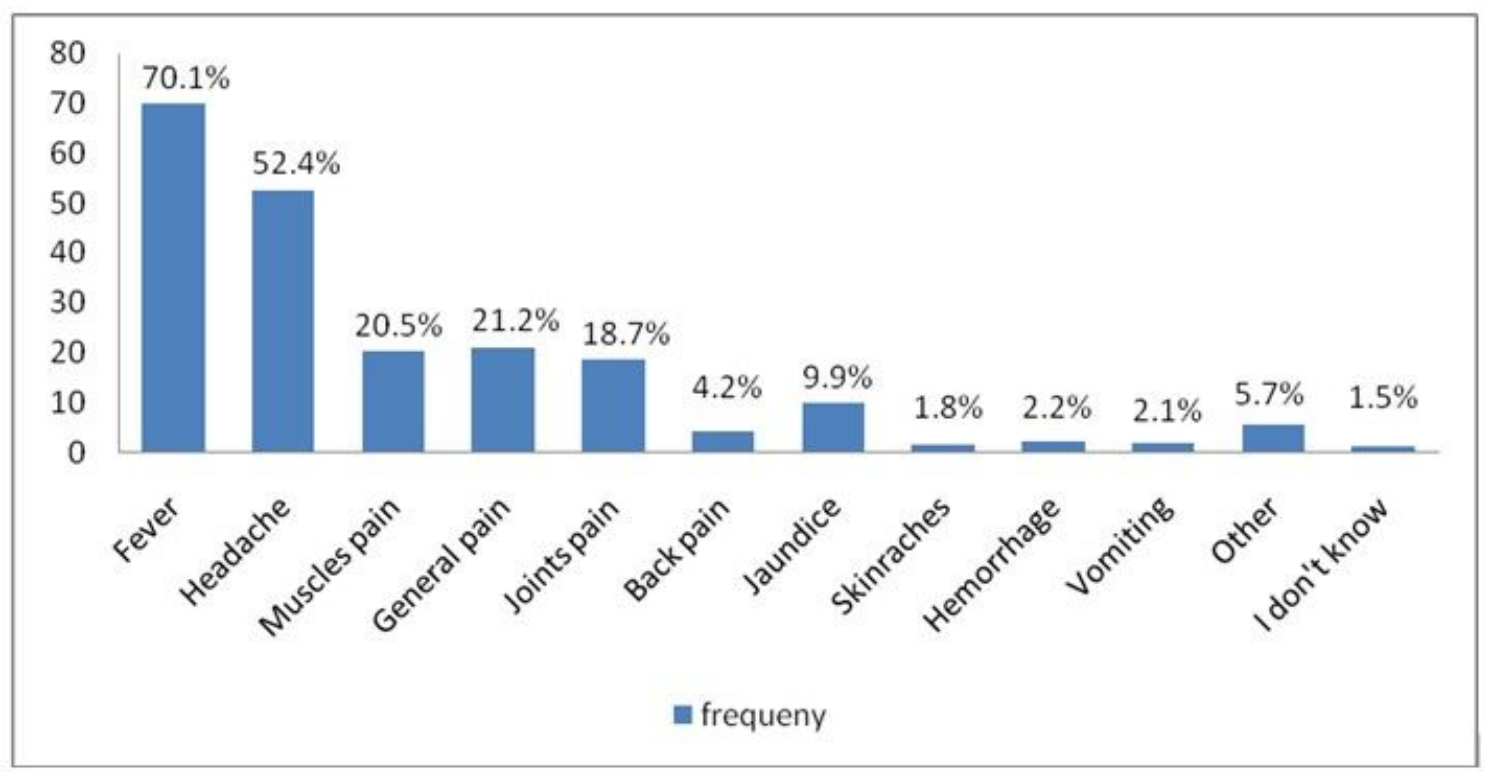

Figure 1: Number of respondents on the knowledge of symptoms of Mosquito-borne viral diseases

Figure 1

Number of respondents on the knowledge of symptoms of Mosquito-borne viral diseases

\section{Supplementary Files}

This is a list of supplementary files associated with this preprint. Click to download.

- ASURVEYOFKapnewtotal.pdf 